\title{
Cloning, pharmacological characterization and tissue distribution of an ORL1 opioid receptor from an amphibian, the rough-skinned newt Taricha granulosa
}

\author{
Eliza A Walthers, C Samuel Bradford and Frank L Moore \\ Department of Zoology, Oregon State University, Corvallis, OR 97331, USA \\ (Requests for offprints should be addressed to F L Moore; Email: mooref@science.oregonstate.edu)
}

\begin{abstract}
We have cloned and characterized an opioid receptor-like (ORL1; also referred to as NOP) receptor from a urodele amphibian, the rough-skinned newt Taricha granulosa The cDNA clone encodes a protein of 368 amino acids that contains the seven hydrophobic domains characteristic of G-protein-coupled receptors, and has the highest sequence identity to the frog (Rana pipiens) nociceptin-like and human ORL1 opioid receptors (79.6 and 68.4\%, respectively). Saturation binding assays on membranes from COS-7 cells transiently expressing the newt ORL1 (nORL) receptor revealed a single, high-affinity (estimated $K_{\mathrm{d}}, 0.1974 \mathrm{nM}$ ) binding site for the ORL1-specific agonist [ $\left.{ }^{3} \mathrm{H}\right]$ orphanin $\mathrm{FQ}$ analog $\left(\left[{ }^{3} \mathrm{H}\right] \mathrm{oFQ}\right)$. In competition binding assays, the $\left[{ }^{3} \mathrm{H}\right] \mathrm{oFQ}$-binding site, like the mammalian ORL1 receptor, had no affinity for the non-selective opioid receptor antagonist naloxone, the $\kappa$-selective agonists U69593 and U50488, or the $\mu$ - and $\delta$-selective opioid receptor agonists DAMGO and DPDPE, respectively. However, the nORL receptor displayed higher affinities for the $\kappa$-selective agonists dynorphin $A(1-13)$, dynorphin $B$, and dynorphin $A(1-8)\left(K_{i}\right.$ values, $2 \cdot 8,151.8$, and $183.0 \mathrm{nM}$, respectively) than its mammalian homologue. The tissue distribution of the $\mathrm{nORL}$ receptor, as determined by reverse transcriptase PCR, was also found to differ from reports on the mammalian ORL1 receptor, with mRNA detected in brain, spinal cord, and lung, but not detected in a number of other peripheral tissues reported to express the receptor in mammals. This is the first report describing the expression and characterization of an amphibian ORL1 receptor, and contributes to our understanding of the evolution of the opioid system.
\end{abstract}

Journal of Molecular Endocrinology (2005) 34, 247-256

\section{Introduction}

The opioid receptor-like (ORL1; also called NOP) receptor is a G-protein-coupled receptor (GPCR) that shares high sequence identity with the three classically recognized opioid receptor types, $\mu, \delta$, and $\kappa$ (Mollereau et al. 1994). The endogenous peptide for the ORL1 receptor, known as orphanin FQ (oFQ; Reinscheid et al. 1995) or nociceptin (Meunier et al. 1995), is a heptadecapeptide whose $\mathrm{N}$-terminal tetrapeptide sequence is related to that of the opioid peptides (FGGF or YGGF), and whose basic core is similar to dynorphin (Dyn), the endogenous peptide for the $\kappa$ receptor. In spite of these similarities, the ORL1 receptor does not recognize the majority of opioid ligands, and oFQ has low affinity for the classic opioid receptors (Reinscheid et al. 1995, Meng et al. 1996a). The ORL1 receptor couples to the same $\mathrm{G}_{\mathrm{i}} / \mathrm{G}_{\mathrm{o}}$ protein-mediated, second-messenger systems as the opioid receptors and produces the inhibition of adenylate cyclase, activation of an inwardly rectifying $\mathrm{K}^{+}$conductance, and inhibition of voltage-sensitive $\mathrm{Ca}^{2+}$ channels (for review, see Meunier 1997). These intracellular effectors generally act to inhibit cellular excitability, and suggest a role for the oFQ/ORL1 system in the modulation of neuronal activity.

Complete cDNA sequences for the $\delta-, \mu-, \kappa-$, and ORL1 opioid receptor types have been obtained for mammals (held in the GenBank nucleotide sequence database), but sequence information for nonmammalian vertebrates is limited. Full-length opioid receptor cDNA sequences have been reported for two species of fish: in the zebrafish Danio rerio, $\delta$ (Barallo et al. 1998, Rodriquez et al. 2000), ORL1 (AY148348), $\mu$ (Barallo et al. 2000), א (AF285173); and in the white sucker Catostomus commersoni, $\mu$ (Darlison et al. 1997). Also in the white sucker, partial cDNA sequences for $\kappa-, \delta$-, and ORL1 receptors have been obtained (Darlison $e t$ al. 1997). In addition, partial fragments for $\delta$ - and $\mu$-like opioid receptors have been amplified from genomic DNA in a more ancient lineage of fish, the pacific hagfish (Eptatretus stoutii; Li et al. 1996), indicating multiple opioid receptor types were present early in vertebrate evolution. Reports on partial genomic DNA sequences for opioid receptors from representatives of different vertebrate classes also include chicken (Gallus domesticus; $\delta, \mu$, ORL1), striped bass (Morone saxatilis; $\delta, \mu, \kappa)$, and 
thresher shark (Alopias vulpinus; $\delta, \mu, \mathrm{ORL1}$; Li et al. 1996). Amphibian opioid receptor sequence fragments have been reported from bullfrog (Rana catesbiana; $\delta, \mu, \kappa)$ genomic DNA (Li et al. 1996), and full-length cDNA sequences for $\mu-, \delta$-, $\kappa$-, and ORL1 opioid receptors were recently submitted to GenBank (accession numbers AF530571, AF530572, AF530573, and AY434690, respectively) for the northern leopard frog (Rana pipiens).

The definitive cDNA sequences recently submitted to GenBank for the opioid receptors in $R$. pipiens correlate with previous pharmacological and behavioral studies indicating that multiple opioid receptor types are present in amphibians. Early binding assays in toad and frog brains indicated the presence of $\mu$-, $\delta$-, and $\kappa$-like opioid-binding sites, and estimated the predominant form of opioid receptor to be $\kappa$-like $(60-70 \%)$, with considerably fewer $\mu$ - and $\delta$-like sites (20-30\%; Simon et al. 1982, 1984). Since these early studies, numerous reports have characterized multiple ORL receptor types $(\mu, \delta, \kappa)$ and subtypes $(\kappa 1, \kappa 2)$ in amphibians (Ruegg et al. 1980, 1981, Simon et al. 1985, 1987, Borsodi et al. 1986, Makimura et al. 1988, Mollereau et al. 1988, Benyhe et al. 1990, 1992 1994, Wollemann et al. 1994, Newman et al. 2002).

In addition to the pharmacological evidence, behavioral studies support the presence of multiple opioid receptor types in amphibians. In amphibians, receptortype-selective opioids have been implicated in the control of nociceptive responses, locomotor activity, and sex behaviors. The opiate morphine sulfate (a $\mu$-receptor agonist) is an analgesic when injected into the spinal cord of $R$. pipiens, and the analgesia is attenuated by naloxone (Pezalla 1983, Stevens \& Pezalla 1983). Also in frogs, spinal administration of Dyn, $\beta$-endorphin, or Met-enkephalin produces a potent, dose-dependent increase in the nociceptive threshold (Stevens et al. 1987). In the rough-skinned newt, Taricha granulosa, the $\kappa$-agonist bremazocine reduces spontaneous locomotor activity, but has no affect on corticotropin-releasing factor-induced locomotion; whereas, morphine does not affect spontaneous locomotion, but does reduce corticotropin-releasing factor-induced locomotion (Deviche et al. 1989, Lowry et al. 1990). Morphine also influences locomotion in $R$. pipiens, where it induces explosive motor behavior when administered systemically (Pezalla 1983). Both bremazocine and ethylketocyclazocine ( $\kappa$ agonists) reduce the incidence of sexual behaviors in $\mathcal{T}$. granulosa, and the effects of both drugs are reversed by naloxone (Deviche \& Moore 1987). These behavioral observations, which are based on the effects of receptor-type-selective opioid agonists, support the presence of multiple opioid receptor types in amphibians.

In the present study we report the cloning and characterization of an amphibian ORLl opioid receptor. The pharmacology of the newt ORL1 (nORL) receptor was determined using saturation and competition binding assays on membranes from COS-7 cells transiently expressing the receptor, and was found to differ from the mammalian ORL1 receptor in its affinity for Dyn-derived peptides. The nORL receptor also has a unique distribution as compared with mammals, with expression in brain, spinal cord, and lung. To the best of our knowledge, this is the first characterization of this type of opioid receptor in an amphibian, and adds to the current body of knowledge on the evolution of the opioid system.

\section{Materials and methods}

\section{PCR with degenerate primers}

Degenerate primers were designed based on highly conserved regions in transmembrane domains (TMs) I and III from multiple opioid receptor types identified in diverse vertebrate phyla ( $\mathrm{Li}$ et al. 1996). The sequences of the sense and the antisense primers were 5 -ACGAAY ATYTACATHTTYAA- ${ }^{\prime}$ and 5'-GGTRAAGATRTT RTAGTARTG-3', respectively (Gibco BRL Custom Primers, Carlsbad, CA, USA). Template cDNA was obtained by reverse transcriptase (RT)-PGR (MBI Fermentas, Hanover, MD, USA) on newt brain total RNA. The degenerate primers $(0 \cdot 5 \mu \mathrm{M})$ and newt brain cDNA template were used in PCR reactions with the following cycling conditions: $2 \mathrm{~min}$ at $94{ }^{\circ} \mathrm{C}, 35$ cycles of $94{ }^{\circ} \mathrm{C}$ for $30 \mathrm{~s}, 50^{\circ} \mathrm{C}$ for $30 \mathrm{~s}$, and $72^{\circ} \mathrm{C}$ for $1 \mathrm{~min}$, followed by a $7 \mathrm{~min}$ extension at $72^{\circ} \mathrm{C}$. Appropriately sized products (approximately $152 \mathrm{bp}$ ) were ligated into the pGEM T-Easy vector and transformed into JM109 Escherichia coli competent cells (Promega, Madison, WI, USA) for amplification. Plasmids were purified by alkaline lysis (Qiagen, Valencia, CA, USA) and sequenced by the Central Services Laboratory at Oregon State University. Sequences were analyzed with a BLAST-N 2.0 (Basic Local Alignment Search Tool) search provided by National Center for Biotechnology Information.

\section{$3^{\prime}$ and $5^{\prime}$ rapid amplification of CDNA ends (RACE)}

The partial sequence (152 bp) of the nORL1 receptor obtained by PGR with degenerate primers (above) was used to design a specific sense primer (5'-CTGGGT GATGCGGTGGTGCTCGT-3') for $3^{\prime}$ RACE. 3' RACE-ready cDNA, synthesized from newt brain RNA according to the SMART RACE cDNA amplification kit protocol (BD Biosciences Clontech, Palo Alto, CA, USA), was used in conjunction with the nORL gene-specific sense primer (One Trick Pony; Ransom Hill Bioscience, Ramona, CA, USA) and the provided Glontech antisense primer in a $3^{\prime}$ RAGE PGR reaction according to the kit protocol and recommended cycling 
conditions. 5' RACE-ready cDNA was synthesized from newt brain RNA according to the Ambion RACE RLM kit protocol (Ambion, Austin, TX, USA). 5' RACE PGR reactions were carried out using the kit reagents and protocol, the provided Outer RACE sense primer, and a 5' RAGE gene-specific antisense primer (5'-TTGGGTT TGTGTGGTGTAGGGATGT-3'), with the following cycling conditions: $94{ }^{\circ} \mathrm{C}$ for $3 \mathrm{~min}$, four cycles of $94{ }^{\circ} \mathrm{C}$ for $45 \mathrm{~s}, 62^{\circ} \mathrm{C}$ for $45 \mathrm{~s}$, and $72{ }^{\circ} \mathrm{C}$ for $1 \mathrm{~min}, 34$ cycles of $94{ }^{\circ} \mathrm{C}$ for $30 \mathrm{~s}, 62^{\circ} \mathrm{C}$ for $30 \mathrm{~s}$, and $72^{\circ} \mathrm{C}$ for $1 \mathrm{~min}$, followed by $72{ }^{\circ} \mathrm{C}$ for $6 \mathrm{~min}$. The RACE PCR products were subcloned and sequenced as described above. Overlapping the $5^{\prime}$ and $3^{\prime}$ RACE product sequences produced a contig that contained the entire nORL1 receptor sequence. The receptor was subsequently PCR-amplified for sequence confirmation three separate times with primers designed at the ends of the coding sequence and a proof-reading polymerase ( $\mathrm{Pfx}$; Invitrogen, Carlsbad, CA, USA).

\section{Tissue distribution of the nORL1 receptor by RT-PCR}

Six rough-skinned newts were cryoanaesthetized and rapidly decapitated. The newts were then dissected, and the following organs were collected and frozen immediately in liquid nitrogen: brain, spinal cord, spleen, small intestine, heart, lung, liver, sperm duct, bladder, and kidney. The tissues were stored at $-80{ }^{\circ} \mathrm{C}$. All experiments were performed in accordance with the National Institutes of Health Guide for the Care and Use of Laboratory Animals and had been approved by the Oregon State University Institutional Animal Care and Use Commitee. The reagents and protocol provided with RNA STAT-60 (Tel-Test, Friendswood, TX, USA) were used to collect total RNA from the tissues. The purified RNA was reverse-transcribed into cDNA using an oligo-dT primer and the Gibco Superscript System for RT-PCR First-Strand Synthesis kit and protocol (Invitrogen). Up to $5 \mu \mathrm{g}$ total RNA from each tissue was used per reverse-transcription reaction. The resultant cDNA was stored at $-20^{\circ} \mathrm{C}$.

Gene-specific primers were designed for PCR based on the nORL receptor sequence. The sense primer (5'-GTGATGGGGTCTGCTGAAAT-3') corresponds to amino acid residues $184-190$ at the start of the putative second extracellular loop of the nORL receptor, and the antisense primer (5'-CACTGCACGAGGAC AAAGAT-3') corresponds to amino acid residues 278-284 at the end of putative TMVI. PCR reactions $(20 \mu \mathrm{l})$ were set up with the specific primers $(0.5 \mu \mathrm{M})$ and the cDNA (10-150 ng) from the collected tissues. The quality and quantity of the cDNA was controlled for in PCR reactions conducted simultaneously using $\beta$-actin primers. The following cycling conditions were used: $94{ }^{\circ} \mathrm{C}$ for $2 \mathrm{~min}, 35$ cycles of $94{ }^{\circ} \mathrm{C}$ for $10 \mathrm{~s}, 60{ }^{\circ} \mathrm{C}$ for
$30 \mathrm{~s}$, and $72{ }^{\circ} \mathrm{C}$ for $1 \mathrm{~min}$, followed by $72{ }^{\circ} \mathrm{C}$ for $5 \mathrm{~min}$. The PCR products were examined by $1.5 \%$ agarose gel electrophoresis and ethidium bromide staining for the nORL-specific amplicon (303 bp) or the actin-specific amplicon (150 bp).

\section{Transfection}

The full-length nORL receptor insert was subcloned into the mammalian expression vector pcDNA3.1/V5His-TOPO (Invitrogen); individual clones were analyzed for correct orientation with respect to the cytomegalovirus promoter. COS-7 cells (ATCG, Manassas, VA, USA) were cultured in $10 \mathrm{~cm}$ tissue-culture plates (Falcon catalog no. 353003 ) at $37^{\circ} \mathrm{C}$ under $5 \% \mathrm{CO}_{2}$ in Dulbecco's modified Eagle's medium (Mediatech Cellgro; Fisher, Pittsburgh, PA, USA) supplemented with $2 \mathrm{mM}$ L-glutamine (Invitrogen) and 10\% fetal bovine serum (Hyclone, Logan, UT, USA). Transient expression was achieved by transfecting plates (90-95\% confluency) using Lipofectamine 2000 (Invitrogen) diluted with Opti-MEM medium (Invitrogen). $6 \mathrm{~h}$ after transfection, the lipofection mixture was aspirated and replaced with fresh growth medium.

\section{Cell harvesting and membrane preparation}

At $48 \mathrm{~h}$ after transfection, cells were washed twice with room temperature PBS and harvested under homogenization buffer (2 ml/plate) using a cell scraper. Suspended cells were homogenized in chilled buffer $(25 \mathrm{mM}$ Hepes, $100 \mu \mathrm{M}$ PMSF, $100 \mu \mathrm{g} / \mathrm{ml}$ trypsin inhibitor, $0 \cdot 7 \mu \mathrm{g} / \mathrm{ml}$ leupeptin, and $100 \mu \mathrm{g} / \mathrm{ml}$ bacitracin) using a chilled Dounce homogenizer. Homogenates were centrifuged for $10 \mathrm{~min}$ at $45000 \boldsymbol{g ~}\left(4^{\circ} \mathrm{C}\right)$. Pellets were resuspended in homogenization buffer $(1 \mathrm{ml} /$ plate $)$ and centrifuged a second time. Cell membrane pellets were resuspended in binding buffer $\left(250 \mu \mathrm{l} /\right.$ plate) containing $\mathrm{MgCl}_{2}$ (see below), snap-frozen in liquid $\mathrm{N}_{2}$, and stored at $-80{ }^{\circ} \mathrm{C}$ until use. In the course of this study, multiple transfections were performed; however, tissues from different transfections were not pooled, and in a given assay all tissues used were obtained from a single transfection. The concentration of total protein in membrane preparations was determined using a colorimetric protein assay (Pierce, Rockford, IL, USA).

\section{Binding assays}

Saturation and competition binding assays were performed in binding buffer consisting of $25 \mathrm{mM}$ Hepes (pH 7.45) containing $10 \mathrm{mM} \mathrm{MgCl}_{2}, 100 \mu \mathrm{M}$ PMSF, trypsin inhibitor $(100 \mu \mathrm{g} / \mathrm{ml})$, leupeptin $(0 \cdot 7 \mu \mathrm{g} / \mathrm{ml})$, and bacitracin $(100 \mu \mathrm{g} / \mathrm{ml})$. Frozen membrane pellets were thawed on ice and diluted with binding buffer to achieve a final protein concentration of $50 \mu \mathrm{g}$ per binding 
reaction. For saturation experiments, variable concentrations of $\left[{ }^{3} \mathrm{H}\right] \mathrm{oFQ}$ analog $(102 \mathrm{Ci} / \mathrm{mmol}$; Multiple Peptide Systems, San Diego, CA, USA) were used in the presence of $10 \mu \mathrm{M}$ nor-BNI (Tocris, Ballwin, MO, USA). Competition binding experiments were performed using $1 \mathrm{nM}\left[{ }^{3} \mathrm{H}\right] \mathrm{oFQ}$ analog and various doses $\left(10^{-12}-10^{-5} \mathrm{M}\right)$ of non-radioactive competitors. Porcine Dyn A (1-8), porcine Dyn A (1-13) amide, and porcine Dyn B were purchased from Phoenix Pharmaceuticals (Belmont, CA, USA); U50488, U69593, naloxone and $\left[\mathrm{D}-\mathrm{Ala}^{2}, \mathrm{NMe}-\mathrm{Phe}^{4}, \mathrm{Gly}-\mathrm{l}^{5}\right]$-enkephalin DAGO (DAMGO) were purchased from Tocris; $\left[\mathrm{D}-\mathrm{Pen}^{2}, \mathrm{D}-\mathrm{Pen}^{5}\right]$-enkephalin (DPDPE) is a product of Multiple Peptide Systems. Non-specific binding was defined as radioactivity remaining bound in the presence of $10 \mu \mathrm{M}$ non-radioactive nociceptin (TOCRIS). Triplicate samples were run at each dose for both total and non-specific binding. Assays were conducted at $4{ }^{\circ} \mathrm{C}$ for $4 \mathrm{~h}$ with gentle mixing (80 r.p.m. on an orbital shaker). At the end of the incubation period, bound and free ligands were separated by rapid filtration over GF/C filters (pre-soaked with $0 \cdot 25 \%$ polyethyleneimine for $30 \mathrm{~min}$ ) under vacuum using a Brandel cell harvester (Brandel, Gaithersburg, MA, USA). Filters were washed twice with $4 \mathrm{ml}$ of chilled $\left(4{ }^{\circ} \mathrm{C}\right.$ ) Hepes $/ \mathrm{MgCl}_{2}$ (pH 7.45) buffer. Radioactivity in the filters was determined by liquid-scintillation counting on a Beckman LS 6500 scintillation counter (GMI, Albertville, MN, USA). Binding data were analyzed using GraphPad Prism software (version 3·0; GraphPad, San Diego, CA, USA).

\section{Results}

\section{Sequence analysis}

Figure 1 shows the nucleotide coding region and its deduced amino acid sequence for the clone isolated by RT-PCR and $5^{\prime}$ and $3^{\prime}$ RACE from newt brain (GenBank accession no. AY728087). The cDNA encodes a protein that is 368 amino acids long and contains seven hydrophobic regions that share identity with the TMs of GPCRs. The deduced amino acid sequence also contains a number of putative consensus sites for post-translational modifications common to characterized GPCRs, including three asparagine residues within the N-terminal domain (glycosylation sites), two cysteine residues in the intracellular C-terminal domain (palmitoylation sites), and a cysteine residue in extracellular loops 1 and 2 (disulfide bridge).

Of the characterized GPCRs, the newt clone shares the highest homology with members of the opioid receptor family, and shares the greatest amino acid sequence identity with the ORL1 type of opioid receptor $(64 \cdot 2-79 \cdot 6 \%)$, compared with $\kappa(54 \cdot 3-56 \%), \delta(51 \cdot 7-$ $53 \cdot 6 \%)$, and $\mu(51 \cdot 2-53 \cdot 6 \%)$. When compared with the human opioid receptor types (ORL1, $\kappa, \delta, \mu)$, there is

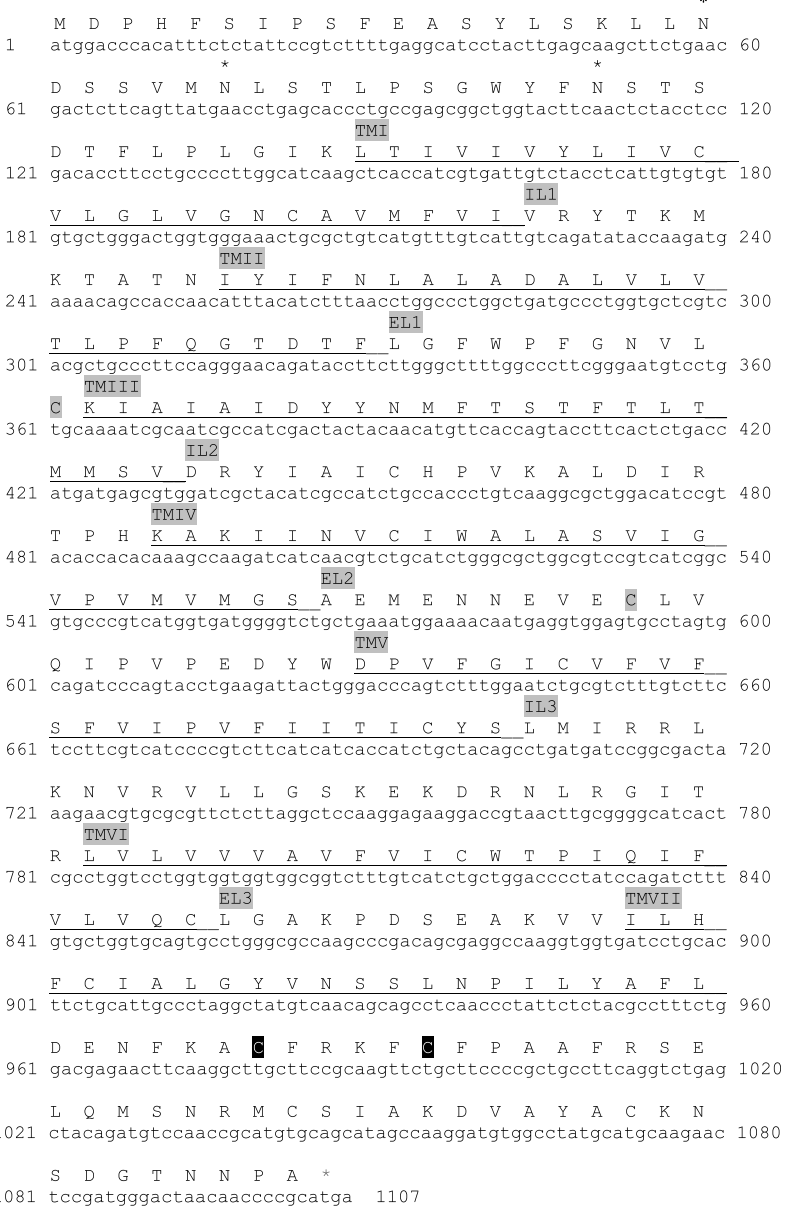

Figure 1 The cDNA nucleotide sequence (GenBank accession no. AY728087) for the coding region of the nORL1 receptor is shown aligned with its deduced amino acid sequence. Underlined regions, putative transmembrane domains (TMs); IL, intracellular cytoplasmic loop; EL, extracellular loop; *, potential glycosylation sites; cysteine residues with light-gray shading, disulfide-bridge formation; cysteine residues with black shading, potential palmitoylation sites.

high sequence identity in the TM regions $(66-77 \%)$ and the intracellular loops (70-81\%). However, the identity between the newt clone and the human ORL1 receptor in the extracellular loops $(60 \%)$ is definitively higher than its identity to $\mu, \delta$, and $\kappa$ in these regions (28-37\%). Furthermore, the second extracellular loop (EL2) of the newt receptor contains a high number of acidic residues, a characteristic shared only by the ORLl and $\kappa$-receptor types.

The deduced amino acid sequence for the nORL1 receptor clone matches a number of residues in the mammalian ORL1 receptor that have been implicated in ligand binding and receptor function by previous studies (Fig. 2). Among these are $\operatorname{Gln}^{286}$ at the C-terminus of TMVI, Asp ${ }^{130}$ and Tyr ${ }^{131}$ in TMIII, 


\begin{tabular}{|c|c|c|}
\hline & \multicolumn{2}{|l|}{-------- MDPHFS IPSFEASYL } \\
\hline & \multicolumn{2}{|l|}{ 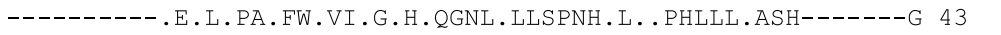 } \\
\hline & \multicolumn{2}{|l|}{ 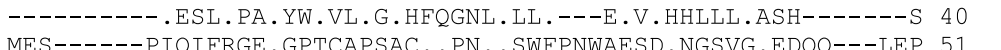 } \\
\hline OR & \multirow{2}{*}{\multicolumn{2}{|c|}{$\begin{array}{ll}\text { MES---- PIQIFRGE. GPTCAPSAC . PN . SWFPNWAESD. NGSVG. EDQQ---LEP } & 51 \\
--1 & \end{array}$}} \\
\hline OR & & \\
\hline IOR & \multicolumn{2}{|l|}{ MDSSTGPGNTS . CSDPLAQASC . PAPGSWLNL . HVDGNQ . DPCGLNRT GLGGNDSLCPQT } \\
\hline & & \\
\hline ORL & \multicolumn{2}{|l|}{ TFLPLGIKLTIVIVYLIVCVLGLVGNCAVMFVIVRYTKMKTATNIYIFNLALADALVLVT } \\
\hline RL1 & \multicolumn{2}{|l|}{ A....L.V...GL.....G..L....Y.................... 103} \\
\hline DRL1 & \multicolumn{2}{|l|}{ 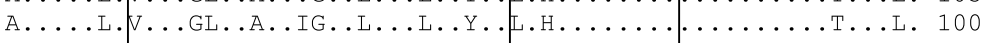 } \\
\hline KOR & \multicolumn{2}{|l|}{ 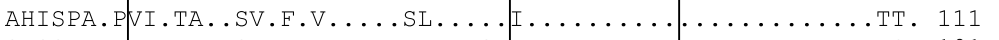 } \\
\hline DOR & \multicolumn{2}{|l|}{ SASS.ALA|IA.TAL.SA. . AV . . L . VLL . . G. . . . . L . . . } \\
\hline IOR & \multicolumn{2}{|l|}{ GSPSMVTAI . MAL.S....V..F.FLL..Y... } \\
\hline & \begin{tabular}{lll} 
EL1 & TMIII \\
\cline { 2 - 2 }
\end{tabular} & \\
\hline RL & \\
\hline RL1 & 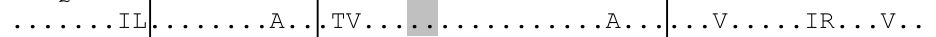 & 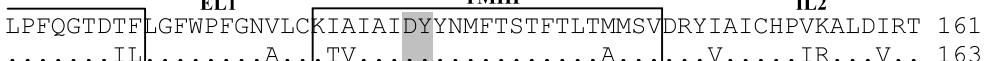 \\
\hline ORL1 & \multicolumn{2}{|l|}{ …IL $[\ldots \ldots$. } \\
\hline OR & \multicolumn{2}{|l|}{ 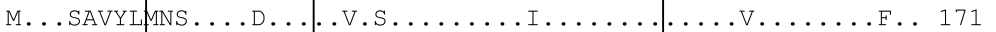 } \\
\hline DOR & \multicolumn{2}{|l|}{ 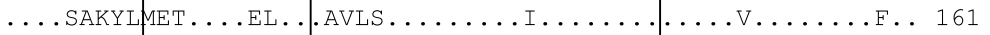 } \\
\hline MOR & \multicolumn{2}{|l|}{....SVNYL } \\
\hline & \\
\hline RL & \multicolumn{2}{|l|}{ PHKAKI INVCIWALASVIGVPVMVMGSAEMENNE--VECLVQI PVPED-YWDPVEFICVE 218} \\
\hline RL1 & \multicolumn{2}{|l|}{ 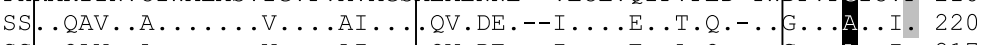 } \\
\hline$R L$ & \multirow{2}{*}{\multicolumn{2}{|c|}{ 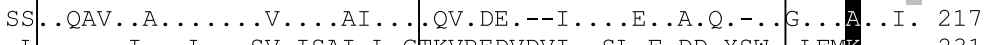 }} \\
\hline & & \\
\hline OR & \multicolumn{2}{|l|}{ 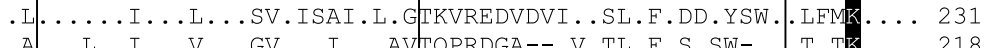 } \\
\hline 1OR & \multicolumn{2}{|l|}{ 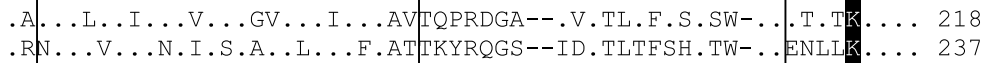 } \\
\hline & \multirow{2}{*}{\multicolumn{2}{|c|}{$\begin{array}{ll}\text { IL3 } & \text { TMVI } \\
\text { VFSFVIPVFIITICYSLMIRRLKNVRVSGSKEKDRNLRRITREVLVVVAVFVICWTPIO } & 278\end{array}$}} \\
\hline & & \\
\hline & L $\ldots$ IV $\ldots$ LV.SV $\ldots \ldots \ldots$ RG $\ldots$ L $\ldots$ R. $\ldots \ldots \ldots \ldots \ldots \ldots$ G. & 280 \\
\hline $2 \mathrm{~T}$ & & \\
\hline & & \\
\hline & IL...V..G. .LLERS & \\
\hline & A.IM.L...V.G...L..S & \\
\hline & & \\
\hline & FLDEI & \\
\hline & & \\
\hline & & \\
\hline & EA...STS-H.T.V. & \\
\hline & JRRDPLV.AA. .L. & \\
\hline IOR & -ETTFQT.SW...... & \\
\hline & & \\
\hline & .L...T.-------ETVPR. .- 370 & \\
\hline & . GLG..T.--------ETVPR. .- 367 & \\
\hline & R-NTVQ.P.SMRDVG---------.M.K.V- 380 & \\
\hline & QAT.RERVT. .TP.------DGPG.GAAA-- 372 & \\
\hline & .Q.N.T.VRQNTREHPST.NTVDRTNHQLENLEAETA.LP 398 & \\
\hline
\end{tabular}

Figure 2 The nORL receptor amino acid sequence is shown aligned with the human ORL1 (hORL1), rat ORL1 (rORL1), rat kappa (rKOR), rat delta (rDOR), and rat mu (rMOR) receptor sequences. Predicted transmembrane domains are boxed and labeled TMI-TMVII. Residues known to be important for ligand affinity or signal transduction from mutagenesis studies on the hORL1 and conserved in the nORL are highlighted in gray (Mouledous et al. 2000). Mutating four residues of the rORL1 to the conserved classical opioid receptor counterparts (Val-Gln-Val ${ }^{276-278}$ to Ile-His-Ile in TMVI and Thr ${ }^{302}$ to Ile in TMVII) enables the receptor to bind prodynorphin peptides with subnanomolar affinity (Meng et al. 1996a); the nORL matches the classical opioid receptors at three of the four residues (black highlights). The addition of a fifth mutation to the rORL1 (Ala to Lys in TMV) increases its affinity towards selective opioid antagonists by two or three orders of magnitude (Meng et al. 1998); the nORL has a unique residue at this position (Gly214; black highlight). Percentage amino acid identities to the nORL are listed at the end of the alignment. EL, extracellular loop; IL, intracellular loop. The included mammalian receptor sequences were obtained from GenBank: ORL1 Homo sapiens, accession no. NP_872588; ORL1 Rattus norvegicus, NP_113757; KOR R. norvegicus, NP_058863; MOR R. norvegicus, NP_037203; DOR R. norvegicus, NP_036749. 


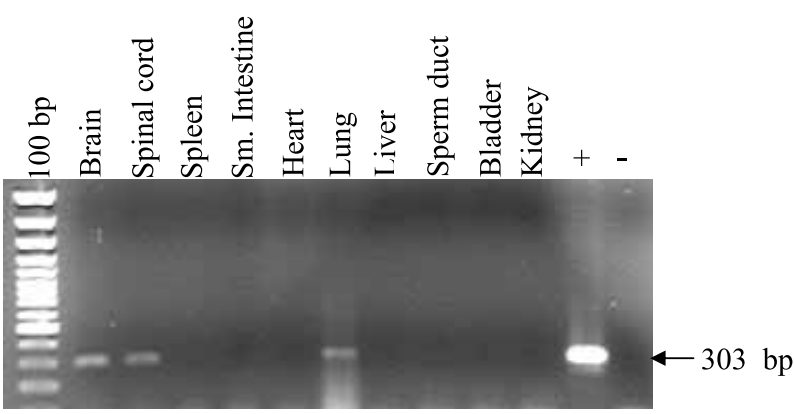

Figure 3 Distribution of the $\mathrm{nORL}$ receptor as determined by RT-PCR. The nORL receptor-specific amplicon (303 bp) was detected in the brain, spinal cord, and lung. +, Positive control; - , no-template control.

$\mathrm{Phe}^{220}$ and $\mathrm{Phe}^{224}$ in TMV, and $\operatorname{Trp}^{276}$ in TMVI (human ORL1 numbering; Mouledous et al. 2000). Also, the newt receptor shares identity with the classic opioid receptors at three residues $\left(\mathrm{Ile}^{277}, \mathrm{Ile}^{279}\right.$, and $\mathrm{Ile}^{303}$; newt numbering) shown to be important in the recognition of $\kappa$ ligands that are not conserved in the mammalian ORL1 receptor (Meng et al. 1996a, 1998).

\section{nORL receptor distribution}

The expression of the nORL receptor in various tissues was determined by RT-PCR on newt brain, spinal cord, spleen, small intestine, heart, lung, liver, sperm duct, bladder, and kidney. The cDNA generated from the tissues was tested in PCR reactions using nORL receptor-specific primers. Appropriately sized amplicons (303 bp) were produced in reactions containing cDNA from brain, spinal cord, and lung (Fig. 3). Negative controls were reactions in which water was substituted for template cDNA. The cDNA from each tissue was also tested in PCR reactions with $\beta$-actin primers to ensure that the template was of sufficient quality and quantity to amplify. The $\beta$-actin primers successfully amplified the cDNA from each tissue (results not shown).

\section{Characterization of the cloned receptor transiently expressed in cOS-7 cells}

Saturation binding of $\left[{ }^{3} \mathrm{H}\right] \mathrm{oFQ}$ analog, an ORL1specific agonist, to membranes of transfected COS-7 cells revealed the presence of a single, high-affinity binding site with an estimated $K_{\mathrm{d}}$ value of $0 \cdot 1974 \mathrm{nM}$ (Fig. 4). At a dose equivalent to the estimated $K_{\mathrm{d}}$ for $\left[{ }^{3} \mathrm{H}\right]$ oFQ specific binding was $94 \cdot 5 \%$ of total binding. No specific binding was detected in membranes prepared from untransfected (control) cells. In competition experiments designed to assess the ability of various opioid ligands to displace $\left[{ }^{3} \mathrm{H}\right] \mathrm{oFQ}$, the $\kappa$ opioid receptor-selective agonist Dyn A (1-13) had high affinity

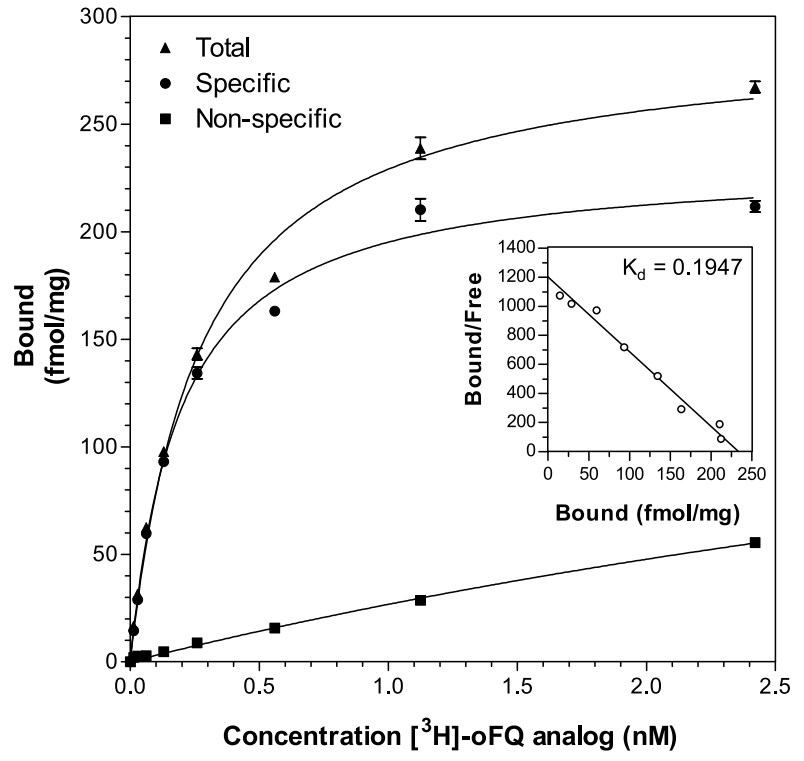

Figure 4 Saturation analysis of $\left[{ }^{3} \mathrm{H}\right] \mathrm{oFQ}$ analog binding to membranes isolated from COS-7 cells transiently expressing nORL receptor. Non-specific binding for each ligand dose was determined in the presence of $10 \mu \mathrm{M}$ nor-BNI. At a dose equivalent to the estimated $K_{d}$ for $\mathrm{OFQ}$ analog, specific binding was $94.5 \%$ of total binding. Each data point represents the mean \pm S.E.M. from triplicate measurements. The inset shows Scatchard analysis.

$\left(K_{\mathrm{i}}, 2 \cdot 76 \mathrm{nM}\right)$, and the $\kappa$ agonists Dyn B and Dyn A (1-8) displayed sub-micromolar affinities $\left(K_{\mathrm{i}}, 151.81\right.$ and $183.03 \mathrm{nM}$, respectively). In contrast, the $\kappa$-selective agonists U50488 and U69593, the non-selective opioid receptor antagonist naloxone, the $\mu$-selective agonist DAMGO, and the $\delta$-selective agonist DPDPE, did not compete for the $\left[{ }^{3} \mathrm{H}\right] \mathrm{oFQ}$-binding site (Fig. 5 and Table 1).

\section{Discussion}

The present study reports the molecular cloning and pharmacological characterization of an amphibian GPCR. The results indicate that the GPCR cloned from newt brain is the homologue of the mammalian ORL1 opioid receptor. This conclusion was reached based on sequence analysis and binding studies with an ORL1selective agonist, $\left[{ }^{3} \mathrm{H}\right]$ oFQ. To the best of our knowledge, this is the first reported characterization of an ORL1 opioid receptor from an amphibian.

Initial BLAST searches on the nucleotide and deduced amino acid sequence of the newt clone indicated it belonged to the GPCR superfamily. The following characteristics of the deduced amino acid sequence supported the GPCR classification: the presence of seven hydrophobic regions that share 


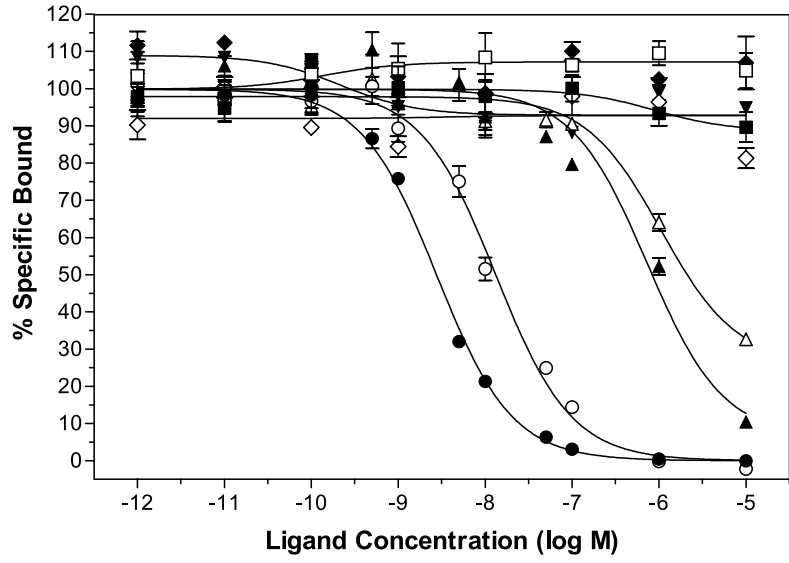

- Nociceptin

- Dynorphin A (1-13)

- Dynorphin B

$\triangle$ Dynorphin A (1-8)

- U50488

口 Naloxone

- U69593

$\diamond$ DAMGO

$\checkmark$ DPDPE

Figure 5 Inhibition of specific $\left[{ }^{3} \mathrm{H}\right] \mathrm{oFQ}$ analog binding to membranes from COS-7 cells transiently expressing nORL receptor. $1 \mathrm{nM}\left[{ }^{3} \mathrm{H}\right] \mathrm{oFQ}$ analog was used in all experiments; non-specific binding was defined as radioactivity remaining bound in the presence of $10 \mu \mathrm{M}$ non-radioactive nociceptin. Each data point represents the mean \pm S.E.M. for triplicate measurements.

sequence identity with the membrane-spanning domains of GPCRs (Minami \& Satoh 1995, Law et al. 1999); asparagine residues within the $\mathrm{N}$-terminal domain that function as potential sites for N-linked glycosylation (Minami \& Satoh 1995); cysteine residues in the intracellular C-terminal domain that are potential palmitoylation sites (Ovchinnikov et al. 1988, O'Dowd et al. 1989); and two cysteine residues, located in extracellular loops 1 and 2, that may connect the loops by forming a disulfide bridge (Dixon et al. 1987, Karnik et al. 1988). In addition, there are a number of serine and threonine residues in the putative cytoplasmic regions, presenting potential sites for phosphorylation by protein kinases. The phosphorylation of homologous sites in GPCRs is a process thought to affect receptor regulation, namely desensitization (Lefkowitz et al. 1990, Law et al. 2000).

Overall, the newt receptor shares $>50 \%$ amino acid sequence identity with the four main opioid receptor types $(\mu, \delta, \kappa$, ORL1) cloned from other species, and has the highest identity to the ORL1 receptors $(>64 \cdot 2 \%)$.
Table 1 Summary of inhibition binding data obtained in experiments designed to assess the ability of various opioid ligands to displace $\left[{ }^{3} \mathrm{H}\right] \mathrm{OFQ}$ analog from membranes of COS-7 cells transiently expressing $\mathrm{nORL}$ receptor

Ligand
ORL-selective
Nociceptin
$\kappa$-Selective
Dynorphin A (1-13)
Dynorphin B
Dynorphin A (1-8)
U50488
U69593
$\mu$-Selective
DAMGO
$\delta$-Selective
DPDPE
Non-selective
Naloxone

\begin{tabular}{|c|c|}
\hline $\mathrm{IC}_{50}(\mathrm{nM})$ & $\boldsymbol{K}_{\mathbf{i}}(\mathrm{nM})$ \\
\hline $2 \cdot 8$ & 0.5 \\
\hline $13 \cdot 3$ & $2 \cdot 8$ \\
\hline $728 \cdot 8$ & $151 \cdot 8$ \\
\hline $916 \cdot 3$ & 183.0 \\
\hline$>10000$ & - \\
\hline$>10000$ & - \\
\hline$>10000$ & - \\
\hline$>10000$ & - \\
\hline$>10000$ & - \\
\hline
\end{tabular}

Of the cloned full-length ORL1 receptors, the newt receptor has the highest amino acid identity to frog $(79 \cdot 6 \%)$ and human $(68 \cdot 4 \%)$, and the lowest to zebrafish $(64 \cdot 2 \%)$. These sequence identities led us to conclude that the newt cDNA codes for an ORL1 receptor. This conclusion was further supported by the high sequence identity $(60 \%)$ between the human and nORL1 receptors in the putative extracellular loops, in contrast to substantially lower sequence identity in these regions when compared with the other opioid receptor types (28-37\%). The extracellular loops may be responsible for the receptor's ability to recognize and discriminate between similar ligands (Wang et al. 1994, 1995, Meng et al. 1996b, Mollereau et al. 1994).

Based on sequence analysis, the nORL1 receptor shares with its mammalian counterpart a number of key residues involved in ligand affinity and receptor activation. The transmembrane domains of opioid receptors form an opioid-binding pocket, a region where specific ligand-receptor interactions cause receptor activation (for review see Waldhoer et al. 2004). The conservation of identity in these regions (66-77\%) suggests the nORL receptor possesses a transmembrane binding pocket similar to the alkaloid binding pocket of the opioid receptors. In particular, five residues within the opioid binding pocket of the human ORL1 receptor are known to greatly influence ligand affinity: $\mathrm{Asp}^{130}$ and Tyr ${ }^{131}$ in TMIII, Phe ${ }^{220}$ and $\mathrm{Phe}^{224}$ in TMV, and $\operatorname{Trp}^{276}$ in TMVI (Mouledous et al. 2000). Mutation to alanine of each of the aforementioned residues has an adverse effect on receptor affinity and reactivity towards oFQ the endogenous ligand of the ORLl receptor (Mouledous et al. 2000). The nORL receptor has the mammalian ORL1 receptor residues at these five sites, 
indicating their functional importance may be highly conserved. In addition, a residue located at the end of TMVI $\left(G \ln ^{286}\right)$, which plays a pivotal role in the transduction of signal in the human ORL1 (Mouledous et al. 2000), is also conserved in the nORL receptor.

Although the nORL receptor has the highest overall sequence identity to the ORL1 receptors, it also shares a number of residues with the classical opioid receptors that are implicated in $\kappa$ ligand recognition. The rat ORL1 receptor was rendered capable of binding Dyn-derived peptides with high affinity after mutating as few as four residues to the conserved classical opioid receptor counterparts (Val-Gln-Val ${ }^{276-278}$ to Ile-His-Ile in TMVI, and $\mathrm{Thr}^{302}$ to Ile in TMVII; Meng et al. 1996a). These amino acid substitutions created a mutant receptor capable of binding both oFQ and prodynorphin products with sub-nanomolar affinity. The addition of a fifth mutation to the rat ORL1 receptor construct $\left(\mathrm{Ala}^{213}\right.$-Lys in TMV) caused its affinity towards selective opioid antagonists to increase two or three orders of magnitude (Meng et al. 1998). Interestingly, the nORL receptor matches the classical opioid receptors at three of the aforementioned residues targeted for mutation (Ile $^{303}$ in TMVII, Ile ${ }^{277}$ and Ile ${ }^{279}$ in TMVI; nORL amino acid numbering). Therefore, we predicted that the nORL receptor pharmacology may differ from its mammalian counterpart in that it may be capable of recognizing both oFQ and Dyn peptides with high affinity.

The results from saturation and competition binding assays performed on membranes from COS-7 cells expressing the nORL receptor supported our prediction that this receptor would have a unique pharmacology. In saturation binding assays, the ORL1-selective agonist $\left[{ }^{3} \mathrm{H}\right] \mathrm{oFQ}$ displayed specific, high-affinity $\left(K_{\mathrm{d}}\right.$, $0 \cdot 1974 \mathrm{nM}$ ) binding to the transfected membranes; oFQ does not bind to the classical opioid receptors, so this result further confirms the identity of the expressed newt clone as an ORL1 receptor. Untransfected cells displayed no specific binding. Results from competition experiments proved interesting. The non-selective antagonist naloxone did not compete with $\left[{ }^{3} \mathrm{H}\right]$ oFQ for the binding site, which is consistent with previous reports on mammalian ORL1 receptors. However, the $\kappa$ opioid receptor-selective agonist, Dyn A (1-13), competed with nanomolar affinity $\left(K_{\mathrm{i}}, 2.76 \mathrm{nM}\right)$ for the $\left[{ }^{3} \mathrm{H}\right] \mathrm{oFQ}-$ binding site. This is in contrast to previous reports demonstrating that Dyn A can bind to the mammalian ORL1 receptor with only moderate affinity (Butour et al. 1997). The high-affinity binding of Dyn A (1-13) to the nORL1 receptor is similar to that seen in the rat ORL1 mutation study (Meng et al. 1996a) described above, and indicates that the same amino acids in the newt receptor may be responsible for ligand specificity. Another Dyn A analog (Dyn A 1-8) displayed moderately high affinity for the binding site $\left(\kappa_{\mathrm{i}}, 183.03 \mathrm{nM}\right)$, as did the $\kappa$-selective agonist Dyn B $\left(K_{\mathrm{i}}, 151 \cdot 81 \mathrm{nM}\right)$. However, two additional $\kappa$-selective agonists, U50488 and U69593, did not compete for the binding site. Therefore, the pharmacological profile of the nORLl receptor is unique among the mammalian profiles thus far reported.

It has been hypothesized that the four opioid precursor genes (proenkephalin, proopiomelanocortin, prodynorphin, and proorphanin) arose by sequential duplication of a common ancestral gene over the past 500 million years, and that the emergence of the cognate receptor proteins $(\delta, \mu, \kappa$, ORLl) paralleled the divergence of the peptide genes (Douglass et al. 1984, Dores et al. 1993, Danielson \& Dores 1999). Recently, the first complete non-mammalian vertebrate proorphanin cDNA gene sequence was obtained from the sturgeon, Acipencer transmontanus (Danielson et al. 2001). The sturgeon oFQ peptide retains the classical opioid peptide core sequence (YGGF), whereas all mammalian oFQ peptides have a modified opioid-like core (FGGF). The sturgeon oFQ with the N-terminal tyrosine, shows affinity for the mammalian ORLl as well as the $\mu, \delta$, and $\kappa$ opioid receptors. The authors suggest that the sturgeon oFQ represents an intermediate stage in the evolution of the proorphanin gene, and a "transitional state in the eventual functional isolation of the orphanin heptadecapeptide from the classical opioids" (Danielson et al. 2001). If this is true, then receptor coevolution may have produced cognate receptor intermediates in some species capable of recognizing oFQ and the classical opioid peptides. Based on the pharmacological profile for the nORL receptor reported here, we could speculate that it is potentially an evolutionary intermediate between the $\kappa$ - and ORL1 receptor types.

The results of the RT-PCR distribution study indicate that nORL receptor mRNA is expressed in brain, spinal cord, and lung. The detection of nORL receptor mRNA in brain and spinal cord was expected, since previous studies have documented high ORL1 receptor densities in the central nervous system (see Mollereau \& Mouledous 2000). However, the peripheral distribution of the nORL receptor is unique when compared with the distribution of the mammalian opioid receptor types. nORL1 receptor mRNA expression was not detected in a number of peripheral tissues shown to express the ORL1 receptor in mammals, including intestine, liver, vas deferens (sperm ducts), and spleen in rat (Wang et al. 1994), and kidney in pig (Osinski et al. 1999). High-affinity $\left[{ }^{3} \mathrm{H}\right]$ nociceptin-binding sites on rat heart (Dumont \& Lemaire 1998), and the ability of oFQ to inhibit contractions of rat bladder (Giuliani et al. 1998), also suggest ORL1 receptor expression in these mammalian organs, although none was detected by RT-PCR in the newt. In the present study, the lung was the one peripheral tissue found to contain nORL receptor mRNA. The ORL1 receptor may be expressed in the lungs of mammals as well, since the oFQ peptide 
can inhibit contractions of guinea-pig bronchus when applied to the isolated organ (Rizzi et al. 1999). Based on the limited peripheral distribution of the nORL receptor, it appears its primary role in this species is in central nervous system processes. Future studies on the specific distribution of the nORL1 receptor in brain and spinal cord will provide additional useful information on interspecific differences.

The results of the present study indicate that an opioid-like receptor cDNA with high sequence identity to the mammalian ORLl receptor is present in an amphibian. The expression of the nORL receptor demonstrated that it is capable of binding both oFQ and prodynorphin peptides with high affinity; a unique pharmacology compared with previous reports on the mammalian ORL1 receptors. In addition to being expressed in brain and spinal cord, nORL receptor mRNA is also localized in the lung; a peripheral distribution that is novel as compared with mammals. The results of the binding assays, sequence information, and distribution studies indicate that the nORL1 receptor may represent an intermediate stage in the evolution of the opioid receptors, and contributes to the current body of knowledge regarding this important neuropeptide system.

\section{Acknowledgements}

We would like to thank Brian Searcy for his technical assistance. E A W thanks Essau M. Perro. We would like to thank NIDA for the gifts of DPDPE and $\left[{ }^{3} \mathrm{H}\right] \mathrm{oFQ}$ analog. This work was supported by NIMH grant no. R01 MH62027. The authors declare that there is no conflicting interest that would prejudice the impartiality of this scientific work.

\section{References}

Barrallo A, Gonzalez-Sarmiento R, Porteros A, Garcia-Isidoro M \& Rodriguez RE 1998 Cloning, molecular characterization, and distribution of a gene homologous to delta opioid receptor from zebrafish (Danio rerio). Biochemical and Biophysical Research Communications 275 544-548.

Barrallo A, Gonzalez-Sarmiento R, Alvar F \& Rodriguez RE 2000 ZFOR2, a new opioid receptor-like gene from the teleost zebrafish (Danio rerio). Brain Research Molecular Brain Research 84 1-6.

Benyhe S, Varga E, Hepp J, Magyar A, Borsodi A \& Wollemann M 1990 Characterization of kappa 1 and kappa 2 opioid binding sites in frog (Rana esculenta) brain membrane preparation. Neurochemical Research 15 899-904.

Benyhe S, Szucs M, Borsodi A \& Wollemann M 1992 Species differences in the stereoselectivity of kappa opioid binding sites for $[3 \mathrm{H}] \mathrm{U}-69593$ and $[3 \mathrm{H}]$ ethylketocyclazocine. Life Sciences $\mathbf{5 1}$ $1647-1655$.

Benyhe S, Simon J, Borsodi A, Wollemann M \& Barnard EA 1994 $\left[{ }^{3} \mathrm{H}\right]$ Dynorphin $_{1-8}$ binding sites in frog (Rana Esculenta) brain membranes. Neuropeptides 26 359-364.
Borsodi A, Khan A, Simon J, Benyhe S, Hepp J, Wollemann M \& Medzihradszky K 1986 Purification of kappa-opioid receptor subtype to apparent homogeneity from frog brain. NIDA Research Monograph 75 1-4.

Butour J, Moisand D, Mazarguil H, Mollereau D \& Meunier J 1997 Recognition and activation of the opioid receptor-like ORL1 receptor by nociceptin, nociceptin analogs and opioids. European Fournal of Pharmacology 321 97-103.

Danielson PB \& Dores RM 1999 Molecular evolution of the opioid/orphanin gene family. General and Comparative Endocrinology 113 169-186.

Danielson PB, Hoverstein MT, Fitzpatrick M, Schreck C, Akil H \& Dores RM 2001 Sturgeon orphanin, a molecular 'fossil' that bridges the gap between the opioids and orphanin FQ/nociceptin. Fournal of Biological Chemistry $27622114-22119$.

Darlison MG, Greten FR, Harvey RJ, Kreienkamp H-J, Stuhmer T, Zwiers H, Lederis K \& Richter D 1997 Opioid receptors from a lower vertebrate (Catostomus commersoni): Sequence, pharmacology, coupling to a G-protein-gated inward-rectifying potassium channel (GIRK1), and evolution. PNAS 94 8214-8219.

Deviche P \& Moore FL 1987 Opioid $\kappa$-receptor agonists suppress sexual behaviors in male rough-skinned newts (Taricha granulosa). Hormones and Behavior $21371-383$.

Deviche P, Lowry CA \& Moore FL 1989 Opiate control of spontaneous locomotor activity in a urodele amphibian. Pharmacology, Biochemistry and Behavior 34 753-757.

Dixon RA, Sigal IS, Candelore MR, Register RB, Scattergood W, Rand E \& Strader CD 1987 Structural features required for ligand binding to the beta-adrenergic receptor. EMBO foumal 11 3269-3275.

Dores RM, McDonald LK, Goldsmith A, Deviche P \& Rubin DA 1993 The phylogeny of enkephalins: speculations on the origins of opioid precursors. Cellular Physiology and Biochemistry 3 231-244.

Douglass J, Civelli O \& Herbert E 1984 Polyprotein gene expression: generation of diversity of neuroendocrine peptides. Annual Review of Biochemistry 53 665-715.

Dumont M \& Lemaire S 1998 Characterization of the high affinity $\left[{ }^{3} \mathrm{H}\right]$ nociceptin binding site in membrane preparations of rat heart: correlations with the non-opioid dynorphin binding site. Fournal of Molecular and Cellular Cardiology 30 2751-2760.

Giuliani S, Lecci A, Tramontana M \& Maggi CA 1998 The inhibitory effect of nociceptin on the micturition reflex in anaesthetized rats. British Fournal of Pharmacology 118 1567-1569.

Karnik SS, Sakmar TP, Chen HB \& Khorana HG 1988 Cysteine residues 110 and 187 are essential for the formation of correct structure in bovine rhodopsin. PNAS 22 8459-8463.

Law PY, Wong YH \& Loh HH 1999 Mutational analysis of the structure and function of opioid receptors. Biopolymers (Peptide Science) $\mathbf{5 1} 440-455$.

Law PY, Wong YH \& Loh HH 2000 Molecular mechanisms and regulation of opioid receptor signaling. Annual Review of Pharmacology and Toxicology 40 389-430.

Lefkowitz RJ, Hausdorff WP \& Caron MG 1990 Role of phosphorylation in desensitization of the beta-adrenoceptor. Trends in Pharmacological Sciences 11 190-194.

Li X, Keith Jr DE \& Evans CJ 1996 Multiple opioid receptor-like genes are identified in diverse vertebrate phyla. FEBS Letters 397 25-29.

Lowry CA, Deviche P \& Moore FL 1990 Effects of corticotropinreleasing factor $(\mathrm{CRF})$ and opiates on amphibian locomotion. Brain Research $\mathbf{5 1 3}$ 94-100.

Makimura M, Ito Y \& Murakoshi Y 1988 Characterization of opioid receptor from bullfrog brain. Fapanese Fournal of Pharmacology $\mathbf{8}$ 359-366.

Meng F, Taylor LP, Hoversten MT, Ueda Y, Ardati A, Reinscheid RK, Monsma FJ, Watson SJ, Civelli O \& Akil H 1996a Moving from the Orphanin FQ receptor to an opioid receptor using four point mutations. Fournal of Biological Chemistry 271 32016-32020. 
Meng F, Ueda Y, Hoverstein MT, Thompson RC, Taylor L, Watson SJ \& Akil H $1996 b$ Mapping the receptor domains critical for the binding selectivity of delta-opioid receptor ligands. European fournal of Pharmacology $311285-292$.

Meng F, Ueda Y, Hoversten HT, Taylor LP, Reinscheid RK, Monsma FJ, Watson SJ, Civelli O \& Akil H 1998 Creating a functional opioid alkaloid binding site in the Orphanin FQ receptor through site-directed mutagenesis. Molecular Pharmacology $53772-777$.

Meunier J-C 1997 Nociceptin/orphanin FQ and the opioid receptor-like ORL1 receptor. European Fournal of Pharmacology $\mathbf{3 4 0}$ $1-15$.

Meunier J-C, Mollereau C, Toll L, Suaudeau C, Moisand C, Alvinerie P, Butour J-L, Guillemot J-C, Ferrara P, Monsarrat B et al. 1995 Isolation and structure of the endogenous agonist of opioid receptor-like $\mathrm{ORL}_{1}$ receptor. Nature 377 532-535.

Minami M \& Satoh M 1995 Molecular biology of the opioid receptors: structures, functions and distributions. Neuroscience Research 23 121-145.

Mollereau C \& Mouledous L 2000 Tissue distribution of the opioid receptor-like (ORL1) receptor. Peptides 21 907-917.

Mollereau C, Pascaud A, Baillat G, Mazarguil H, Puget A \& Meunier J-C 1988 Evidence for a new type of opioid binding site in the brain of the frog Rana ridibunda. European Fournal of Pharmacology 150 75-84.

Mollereau C, Parmentier M, Mailleux P, Butour JL, Moisand C, Chalon P, Caput D, Vassart G \& Meunier J-C 1994 ORL1, a novel member of the opioid receptor family. Cloning, functional expression and localization. FEBS Letters 341 33-38.

Mouledous L, Topham CM, Moisand C, Mollereau C \& Meunier J-C 2000 Functional inactivation of the nociceptin receptor by alanine substitution of glutamine 286 at the $\mathrm{C}$ terminus of transmembrane segment VI: evidence from a site-directed mutagenesis study of the ORL1 receptor transmembrane-binding domain. Molecular Pharmacology 52 495-502.

Newman LC, Sands SS, Wallace DR \& Stevens CW 2002 Characterization of mu, kappa, and delta opioid binding in amphibian whole brain tissue homogenates. Fournal of Pharmacology and Experimental Therapeutics $301364-370$.

O'Dowd BF, Hnatowich M, Caron MG, Lefkowitz RJ, \& Bouvier M 1989 Palmitoylation of the human beta 2-adrenergic receptor. Mutation of Cys341 in the carboxyl tail leads to an uncoupled nonpalmitoylated form of the receptor. Fournal of Biological Chemistry 264 12657-12665.

Osinski MA, Pampusch MS, Murtaugh MP \& Brown DR 1999 Cloning, expression and functional role of a nociceptin/orphanin FQ receptor in the porcine gastrointestinal tract. European fournal of Pharmacology 365 281-289.

Ovchinnikov YuA, Abdulaev NG \& Bogachuk AS 1988 Two adjacent cysteine residues in the $\mathrm{C}$-terminal cytoplasmic fragment of bovine rhodopsin are palmitylated. FEBS Letters $2301-5$

Pezalla PD 1983 Morphine-induced analgesia and explosive motor behavior in an amphibian. Brain Research 273 297-305.

Reinscheid RK, Nothacker H-P, Bourson A, Ardat A, Henningsen RA, Bunsow JR, Grandy DK, Langen H, Monsma Jr FJ \& Civelli
O 1995 Orphanin FO: a neuropeptide that activates an opioid like G protein-coupled receptor. Science 270 792-794.

Rizzi A, Calo G, Trevisani M, Tognetto M, Fabbri L, Mapp C, Guerrini R, Salvadori S, Regoli D \& Geppetti P 1999 Nociceptin receptor activation inhibits tachykinergic non adrenergic non cholinergic contraction of guinea pig isolated bronchus. Life Sciences 64 PL157-PL163.

Rodriguez RE, Barrallo A, Garcia-Malvar F, McFadyen IJ, Gonzalez-Sarmiento R \& Traynor JR 2000 Characterization of ZFOR 1, a putative delta-opioid receptor from the teleost zebrafish (Danio rerio). Neuroscience Letters 288 207-210.

Ruegg UT, Hiller JM \& Simon EJ 1980 Solubilization of an active opiate receptor from Bufo marinus. European Fournal of Pharmacology $64367-368$.

Ruegg UT, Cuenod S, Hiller JM, Gioannini TC, Howells RD \& Simon EJ 1981 Characterization and partial purification of solubilized active opiate receptor from toad brain. PNAS $\mathbf{7 8}$ 4635-4638.

Simon EJ, Hiller JM, Groth J, Itzhak Y, Holland MJ \& Beck SG 1982 The nature of opiate receptors in toad brain. Life Sciences $\mathbf{3 1}$ $1367-1370$

Simon J, Szucs M, Benyhe S, Sorsodi A, Zeman P \& Wollemann M 1984 Solubilization and characterization of opioid binding sites from frog (Rana esculenta) brain. Fournal of Neurochemistry $\mathbf{4 3}$ 957-963.

Simon J, Benyhe S, Borsodi A, Szucs M \& Wollemann M 1985 Separation of kappa-opioid receptor subtype from frog brain. FEBS Letters 183 395-397.

Simon J, Benyhe S, Hepp J, Khan A, Borsodi A, Szucs M, Medzihradszky K \& Wollemann M 1987 Purification of a kappa-opioid receptor subtype from frog brain. Neuropeptides $\mathbf{1 0}$ 19-28.

Stevens CW \& Pezalla PD 1983 A spinal site mediates opiate analgesia in frogs. Life Sciences 33 2097-2103.

Stevens CW, Pezalla PD \& Yaksh TL 1987 Spinal antinociceptive action of three representative opioid peptides in frogs. Brain Research 402 201-203.

Waldhoer M, Bartlett S, \& Whistler J 2004 Opioids receptors. Annual Review of Biochemistry 73 953-990.

Wang JB, Johnson PS, Imai Y, Persico AM, Ozenberger BA, Eppler CM \& Uhl GR 1994 cDNA cloning of an orphan opiate receptor gene family member and its splice variant. FEBS Letters $\mathbf{3 4 8}$ $75-79$.

Wang WW, Shahrestanifar M, Jin J \& Howells RD 1995 Studies on mu and delta opioid receptor selectivity utilizing chimeric and site-mutagenized receptors. PNAS 92 12436-12440.

Wollemann M, Farkas J, Toth G \& Benyhe S 1994 Characterization of $\left[{ }^{3} \mathrm{H}\right]$ Met-Enkephalin-Arg ${ }^{6}-\mathrm{Phe}^{7}$ binding to opioid receptors in frog brain membrane preparations. Fournal of Neurochemistry 63 $1460-1465$

Received 5 November 2004

Accepted 30 November 2004 